STANISŁAW MORDWA

Uniwersytet Łódzki

Wydział Nauk Geograficznych

Katedra Studiów Ludnościowych i Badań nad Usługami

\title{
PERCEPCJA ZAGROŻEŃ SPOŁECZNO- -PRZESTRZENNYCH W MIEŚCIE A SUBIEKTYWNE RYZYKO WIKTYMIZACYJNE I ZACHOWANIA OBRONNE OSÓB W WIEKU POWYŻEJ 60 LAT
}

THE PERCEPTION OF THE SOCIO-SPATIAL THREATS IN THE CITY AND A SUBJECTIVE RISK OF VICTIMIZATION AND DEFENSIVE BEHAVIOR OF PEOPLE AGED OVER 60 YEARS

Artykuł wpłynął do redakcji 10.12.2015; po recenzjach zaakceptowany 23.02.2016.

Mordwa S., 2015, Percepcja zagrożeń społeczno-przestrzennych $w$ mieście a subiektywne ryzyko wiktymizacyjne i zachowania obronne osób $w$ wieku powyżej 60 lat, [w:] Janiszewska A. (red.), Jakość życia ludzi starych - wybrane problemy, „Space - Society - Economy”, 14, Department of Population and Services Studies, Wydawnictwo Uniwersytetu Łódzkiego, Łódź, s. 101-120.

Dr hab. Stanisław Mordwa, prof. UŁ, Uniwersytet Łódzki, Katedra Studiów Ludnościowych i Badań nad Ustugami, ul. Kopcińskiego 31, 90-142 Lódź; e-mail:most@geo.uni.lodz.pl

\section{Zarys treści}

Przestrzeń miasta może być źródłem różnych zagrożeń, które oddziałują na poziom poczucia bezpieczeństwa jego mieszkańców. W artykule dokonano analizy różnych aspektów zachowań obronnych mieszkańców, które podejmowane są jako skutek percepcji różnorodnych i zróżnicowanych przestrzennie zagrożeń występujących w Łodzi oraz subiektywnego ryzyka wiktymizacji 
odczuwanego przez osoby w wieku senioralnym. Zachowania obronne mieszkańców w przestrzeni miasta, są bowiem reakcją na realne bądź percypowane zagrożenia tam występujące.

\section{Slowa kluczowe}

Ludzie starzy, zachowania obronne, poczucie bezpieczeństwa, zagrożenia społeczno-przestrzenne, ryzyko wiktymizacji, Łódź.

\subsection{WPROWADZENIE}

Starzenie się społeczeństw to zjawisko, którego intensywność w ostatnich latach znacznie wzrasta. Szczególnie jest to widoczne w państwach wysoko rozwiniętych, co w połączeniu z jednoczesnym spadkiem przyrostu naturalnego sprawia, że odsetek ludzi starych w społeczeństwie szybko rośnie. Przyjmuje się, że jest to efekt wydłużania się ludzkiego życia, postępu cywilizacyjnego i poprawy jakości życia. Oprócz wzrostu ilościowego starszej populacji, obserwowany jest wzrost jej udziału w strukturze ludności, co z kolei przy jednoczesnym spadku udziału najmłodszych grup wiekowych, uznawane jest za zjawisko szczególnie niepokojące dla dalszego funkcjonowania i rozwoju społeczeństw.

W bogatej literaturze poświęconej procesom starzenia się społeczeństw jako próg starości przyjmuje się wiek 60 lub 65 lat $^{1}$. W tym opracowaniu za osoby w starszym wieku przyjęto traktować ludność w wieku 60 lat i więcej. Na przykład, zgodnie z psychologiczną koncepcją cyklu życia - stworzoną przez E.H. Eriksona (2002) - życie jednostki można podzielić na osiem etapów. Ostatni etap, czyli późna dorosłość, zaczyna się w wieku 60-65 lat. Ten ostatni etap życia człowieka również można podzielić, ale podziały te ulegają zmianom wraz z wydłużaniem się życia zbiorowości osób starszych (por. Synak 2000, s. 10). Obecnie w literaturze anglosaskiej stosuje się podział starości na trzy fazy:

- młodzi starzy (young old) - osoby w wieku 60/65-74 lata,

- starzy starzy (old old) - osoby w wieku 75-84 lata,

- najstarsi starzy (the oldest old) - osoby w wieku 85 lat i więcej.

Młodzi starzy to osoby najczęściej jeszcze w pełni sprawne fizycznie i psychicznie. Osoby zaliczane do kategorii starzy starzy to osoby wymagające niejednokrotnie pomocy w wykonywaniu niektórych czynności, np.: robienie zakupów, sprzątanie, pranie. Najstarsi starzy potrzebują natomiast stałej pomocy podczas wykonywania większości czynności. W Polsce przyjmuje się, że osoby w wieku 75-80 lat, wymagają podczas codziennej egzystencji pomocy dochodzącego opiekuna lub pomocy oferowanej przez wyspecjalizowane instytucje (DPS, ZOL itp.).

\footnotetext{
${ }^{1}$ Na przykład E. Rosset (1959) postulował przyjęcie dwojakiego rozumienia starości - w rozumieniu biologicznym (jej umowny początek to ukończenie 60 lat) oraz w znaczeniu ekonomicznym (z ukończeniem 65 lat).
} 
Starzenie się populacji zmusza pozostałą część społeczeństwa do zmierzenia się z problemami i potrzebami charakterystycznymi dla grupy osób starszych. Ze specyfiki różnych problemów dotykających seniorów wynikają także ich potrzeby związane ze: stylem życia, zdrowiem i opieką, sferą psychospołeczną, aktywnością społeczną, aktywnością zawodową, sytuacją materialną oraz edukacją. Dlatego do zadań wielu instytucji należy zorganizowanie osobom w wieku senioralnym pomocy związanej z: sytuacją życiową, zdrowiem i sprawnością fizyczną, opieką i pomocą w podstawowych czynnościach, opieką długoterminową i hospicyjną, wsparciem psychologicznym, poczuciem bezpieczeństwa, rekreacją i rozwojem zainteresowań oraz ze wzmacnianiem i wykorzystaniem potencjału osób starszych (Instytucje wobec potrzeb... 2010). Przedmiotem tego opracowania są zachowania obronne osób w wieku 60 wzwyż, będące reakcją na percepcję ryzyka wiktymizacji oraz poziom zagrożeń społeczno-przestrzennych w mieście.

Zapewnienie dobrego życia swoim obywatelom powinno być głównym zadaniem każdego państwa, a potrzeba bezpieczeństwa jest jedną z kluczowych potrzeb człowieka odczuwaną przez całe życie. W opracowaniach dotyczących analizy ludzkich potrzeb kwestie związane z bezpieczeństwem człowieka przeważnie wysuwane są na pierwszy plan. Tak jest w hierarchicznej teorii potrzeb A. Maslowa, teorii kultury B. Malinowskiego czy teoriach C. Alderfera (ERG) i H. Murray'a (bezpieczeństwo rozumiane jako potrzeba unikania urazów fizycznych i psychicznych). Uważa się, że bezpieczeństwo należy do tych najbardziej podstawowych potrzeb, które są konieczne do normalnego funkcjonowania ludzi i społeczeństw. $Z$ opracowań wielu autorów wynika, że ogólny poziom poczucia bezpieczeństwa oraz poziom różnych zagrożeń uzależniony jest od wielu cech społeczno-demograficznych respondentów. Jedną z takich podstawowych cech jest wiek osób badanych (Czapska 2008; Jabkowski 2008; Mordwa 2010, 2011, 2012, 2013, 2015; Jerschina z zespołem 2012; Jabkowski, Kilarska 2013). Na przykład, przytoczone w Diagnozie społecznej wyniki wskazują na to, że poczucie zagrożenia zjawiskami patologii społecznej w miejscu zamieszkania towarzyszy osobom w każdym wieku. Poziom zagrożenia jest przy tym szczególnie wysoki w przypadku ludzi po 60. roku życia - wśród nich odsetek osób mających takie obawy dochodzi do 44\% (Czapiński, Panek 2009, s. 28). W wynikach badań prezentowanych przez P. Jabkowskiego i A. Kilarską (2013, s. 170-179) widać utrzymujące się na podobnym poziomie wartości poczucia bezpieczeństwa w kategoriach respondentów do 55 roku życia i znaczny ich spadek w kategoriach osób starszych. Ponadto osoby powyżej 65 roku życia charakteryzuje bardzo wysoki poziom poczucia zagrożenia, nieporównywalny z innymi grupami wieku.

Współczesne definicje określają bezpieczeństwo jako stan pewności, spokoju, braku zagrożeń oraz ochrony przed zagrożeniami. Pojęcie zagrożenia odnosi się natomiast do sfery świadomości danej osoby. Jest ono wywołane przez negatywną ocenę postrzeganych zjawisk. Percepcja zagrożeń przez ludzi, a zatem ich 
poczucie bezpieczeństwa jest odzwierciedleniem realnego lub potencjalnego zagrożenia. Oznacza to, że percepcja ta może być zgodna lub niezgodna ze stanem faktycznym. Zgodnie z modelem objaśniania bezpieczeństwa D. Freia możliwe jest wystąpienie następujących sytuacji (za: Zięba 1997):

- stan braku bezpieczeństwa zachodzi wtedy, kiedy występuje duże rzeczywiste zagrożenie zewnętrzne, a postrzeganie tego zagrożenia jest prawidłowe,

- stan obsesji występuje wtedy, gdy nieznaczne zagrożenie postrzegane jest jako duże,

- stan fałszywego bezpieczeństwa występuje wówczas, gdy zagrożenie zewnętrzne jest poważne, a postrzegane bywa jako niewielkie,

- stan bezpieczeństwa notujemy wtedy, gdy zagrożenie zewnętrzne jest nieznaczne, a jego postrzeganie prawidłowe.

Na podstawie badań wspomnianych wyżej autorów, spośród powyższych czterech sytuacji, ludziom starszym najbliższy jest stan obsesji - bowiem w różnych opisywanych sytuacjach ze wszystkich grup wiekowych, to zawsze oni odczuwają największe zagrożenie, które powoduje np. uczucia lęku i strachu, czy też paraliżuje aktywność w przestrzeni. Z. Bauman (2004) postawił diagnozę, że w konsekwencji zmian jakie zachodzą we współczesnym świecie coraz więcej ludzi przechodzi z bezpiecznego i szczęśliwego grona osób mogących pozwolić sobie na satysfakcjonujące życie, do świata egzystencjalnego lęku oraz niepokoju o własny byt. Wydaje się, że w tej drugiej grupie znalazła się większość ludzi w wieku 60+. Dlatego dla lepszej jakości ich życia tak ważna jest prawidłowa percepcja potencjalnych zagrożeń występujących w danym środowisku społeczno-przestrzennym.

Zachowania obronne mieszkańców Łodzi kilkukrotnie badał już S. Mordwa (2010, 2011, 2012, 2013), aczkolwiek tylko te zachowania, które były reakcją na zagrożenie przestępczością. W publikacjach tych zaobserwowano kilka prawidłowości. Okazało się na przykład, że bardzo istotne są różnice w zachowaniach obronnych między mieszkańcami poszczególnych osiedli miasta. Mimo wysokiego poczucia zagrożenia przestępstwami prawie $1 / 4$ respondentów nie podejmowała żadnych działań ochronnych (osobami, które nie stosują żadnych środków zabezpieczeń były głównie osoby młode, w równym stopniu kobiety co mężczyźni). Stosowanie większej liczby zabezpieczeń częściej deklarowały kobiety i osoby starsze, ale zdecydowanie częściej wybierały one zachowania pasywne, polegające na unikaniu niechcianych sytuacji zagrożenia. Osoby powyżej 51. roku życia stosowały głównie schodzenie z drogi określonym grupom osób.

Celem tego opracowania jest weryfikacja hipotezy, zgodnie z którą percepcja zagrożeń o charakterze społeczno-przestrzennym, występujących w środowisku mieszkaniowym osób starszych oraz ich subiektywne ryzyko wiktymizacji znajduje swoje odzwierciedlenie w podejmowanych przez te osoby zachowaniach obronnych. 


\subsection{CHARAKTERYSTYKA PROJEKTU BADAWCZEGO I OBSZARU BADAŃ}

Podstawowym źródłem informacji wykorzystanym w tym opracowaniu były wywiady kwestionariuszowe, które obejmowały problematykę dotyczącą m.in. percepcji zagrożeń i poczucia bezpieczeństwa. Wywiady te na obszarach Centrum-Północ (160 wywiadów), Centrum-Południe (150), Karolewa (150), Radiostacji (130) i Dołów (120) przeprowadzono w latach 2011-2012, w ramach projektu Dysproporcje spoleczne i gospodarcze w przestrzeni Łodzi. Czynniki, mechanizmy, skutki - którego wyniki zostały opublikowane w pracy pod redakcją A. Suliborskiego i M. Wójcika (2014). Razem uzyskano opinie od 710 przypadkowo spotkanych, dorosłych respondentów, dobranych w sposób celowo-losowy, według ich zamieszkania. Wśród badanych były 152 osoby, które ukończyły 60 lat $(21,4 \%)$. Były to 102 kobiety (67\%) i 50 mężczyzn. Zbadano opinie 122 osób w wieku 60-74 lata (80,3\%), 27 osób starych-starych (17,8\%), i trzy opinie najstarszych starych ${ }^{2}$ (pow. 85 lat) $-2 \%$.

Ankietowani seniorzy byli osobami słabiej wykształconymi niż przeciętni łodzianie, co jest konsekwencją wieku osób, które wzięły udział w badaniach. $10,5 \%$ respondentów zadeklarowało wykształcenie wyższe (magisterskie lub licencjackie), 31,6\% wykształcenie średnie, a aż 57,9\% miało wykształcenie zasadnicze, podstawowe, niepełne podstawowe lub brak wykształcenia.

Wśród ankietowanych osób co najmniej 60-letnich najwięcej było osób owdowiałych $(54,6 \%)$ i pozostających w związku małżeńskim (40,8\%). Pozostałe osoby to jeden kawaler, jedna panna i pięcioro rozwiedzionych. Razem respondenci pozostający w stanie wolnym stanowili 59,2\% ankietowanych.

Przed rozpoczęciem badań uznano, że także długość okresu zamieszkania respondentów na badanym obszarze może istotnie różnicować wyrażane opinie. $25 \%$ badanych seniorów przebywało na jednym z pięciu wybranych obszarów od urodzenia, a dalsze 58,6\% mieszkało tam co najmniej od 10 lat-wydaje się, że te dwie grupy badanych szczególnie dobrze znają zamieszkiwane obszary.

Badania zostały przeprowadzone w pięciu obszarach Łodzi pokrywających się z czterema obszarami SIM (Systemu Informacji Miejskiej): Centrum (na potrzeby badań podzielone na część północną i południową), Karolew, Radiostacja i Doły. W wyborze obszarów kierowano się odmiennością ich typów zabudowy mieszkaniowej i pełnionych funkcji oraz charakterystyką demograficzną mieszkańców. Obszar SIM Centrum obejmuje najbardziej prestiżowe tereny i lokalizacje w skali całego miasta, ale także sąsiadujące z nimi kwartały koncentracji biedy, ubóstwa i innych patologii społecznych (Grotowska-Leder 2001; Warzywoda-Kruszyńska

${ }^{2}$ Ze względu na małe liczebności w dalszych analizach połączono dwie najstarsze grupy wiekowe respondentów. 
2001; Mordwa 2014). Przeważa na tym obszarze zabudowa śródmiejska o bardzo zróżnicowanym standardzie mieszkań: od w pełni wyposażonych, luksusowych lokali, po budynki substandardowe (Dzieciuchowicz 2011). Centrum, ze względu na znaczne rozmiary, podzielono na dwa obszary badań : Centrum-Północ i Centrum-Południe wzdłuż al. A. Mickiewicza i al. J. Piłsudskiego, gdyż obszary te mają różny charakter. Część północna to zwarta zabudowa XIX-wiecznych kamienic (zawierających funkcje mieszkalno-usługową), północny fragment ulicy Piotrkowskiej pełni funkcję deptaka (o ograniczonym ruchu pojazdów), a różnorodne działania w tym miejscu mają przywrócić tej ulicy dawną świetność jako wizytówki i salonu miasta. Południowy fragment ul. Piotrkowskiej pełni normalne funkcje komunikacyjne, a okoliczne obszary są w większym stopniu zdezorganizowane przestrzennie, przenikają się tutaj tereny mieszkaniowe z obszarami składowymi, poprzemysłowymi czy ugorami miejskimi. Charakterystyczne dla Karolewa jest duże zagęszczenie podobnych do siebie budynków wznoszonych metodą wielkopłytową. Jest to zabudowa blokowa pochodząca z drugiej połowy lat 60 ., silnie zróżnicowana pod względem liczby kondygnacji i liczby lokali mieszkalnych wyposażonych w podstawowe instalacje, ale przeważnie o małej powierzchni użytkowej. Radiostacja znajduje się we wschodniej części Śródmieścia. Dominują tu tereny o przewadze zabudowy wielorodzinnej, w części południowej znajdują się tereny o przewadze zabudowy jednorodzinnej. Pomiędzy tymi terenami mieszkaniowymi znajduje się strefa $\mathrm{z}$ dominującą funkcją usług o charakterze metropolitalnym z wtrąceniami zabudowy czynszowej i modernistycznymi willami. W skali całego miasta warunki mieszkaniowe na obszarze Radiostacji wyróżniają się bardzo pozytywnie (Dzieciuchowicz 2011). Mieszkańcy Łodzi powszechnie kojarzą obszar Dołów z kompleksem cmentarzy różnych wyznań, stanowiącym aż $21 \%$ powierzchni tego osiedla. Ponadto znajdują się tutaj również tereny: usług o charakterze metropolitalnym, zabudowy mieszkaniowej - jednorodzinnej, zabudowy mieszkaniowej wielorodzinnej, o funkcjach przemysłowo-usługowych.

Wśród badanych seniorów 33 osoby zamieszkiwało obszar Centrum-Południe, nieco mniej Centrum-Północ (30). Doły i Karolew reprezentowało po 27 osób $\mathrm{w}$ wieku $60+$. Najwięcej osób należących do badanej grupy wiekowej zamieszkiwało Radiostację (35 osób).

\subsection{OCENA ZAGROŻEŃ WYBRANYMI PROBLEMAMI SPOLECZNYMI I PRZESTRZENNYMI}

Respondenci, na podstawie przedłożonego spisu problemów, mieli za zadanie dokonać oceny ich znaczenia na zamieszkiwanym obszarze. W tym celu wybierali rangi od 1 (co oznaczało, że dany problem nie jest istotny) do 5 (bardzo poważny problem). Poszczególne problemy uporządkowano nadając im hierarchię, którą 
ustalono na podstawie różnicy między sumą rang 4 i 5 (czyli odpowiedzi oceniających dany problem jako ważny lub bardzo ważny) oraz rang 1 i 2 (określających problem jako mały bądź nieistotny). W efekcie tego zabiegu okazało się, że zdaniem wszystkich 710 respondentów najważniejsze problemy występujące w wybranych do badań obszarach to: bezrobocie (poważny i bardzo poważny problem dla 50\% respondentów), za mało policji i straży miejskiej na ulicach (50\%), pijacy na ulicy (46\%), grupy watęsajacej się młodzieży (49\%) oraz wandalizm (48\%). Okazało się, że ogół respondentów w większości nie zauważał istnienia w swojej okolicy takich problemów, jak: narkomani i handlarze narkotyków (chociaż był to poważny i bardzo poważny problem dla $26 \%$ respondentów), napastowanie kobiet $i$ dziewczat (29\%), za duży hałas $(30 \%)$, przemoc $w$ rodzinie $(36 \%)$, zle oświetlenie ulic (35\%) (Mordwa 2014).

Według respondentów, którzy ukończyli co najmniej 60 lat, hierarchia problemów występujących w okolicy ich miejsca zamieszkania była nieco inna. Seniorzy uważali, że więcej problemów zidentyfikowanych w łódzkich osiedlach ma poważne nasilenie; częściej korzystali bowiem z rang 4 i 5, które wskazywały na powagę danego problemu. Okazało się, że najważniejsze problemy na pięciu obszarach badań stanowiły (rys. 1): bezrobocie (poważny i bardzo poważny problem dla $62 \%$ respondentów), grupy watęsającej się młodzieży (61\%), za mało policji i straży miejskiej na ulicach (59\%), bieda (49\%) oraz wandalizm (55\%). Ponadto przewage opinii o dokuczliwości danego problemu stwierdzono jeszcze w przypadku: brud $i$ śmieci na ulicach $i$ w parkach, pijacy na ulicy, napisy/graffiti na murach, dostep do pomocy społecznej, złe oświetlenie ulic, przestępczość, bezdomni i żebracy, zrujnowane/zaniedbane budynki oraz za duży hatas. Tylko cztery problemy (przemoc w rodzinie, możliwości spędzania wolnego czasu, narkomani i handlarze narkotyków, napastowanie kobiet $i$ dziewcząt) badani seniorzy uznali za nieistotne lub mało istotne w swojej okolicy (w tych przypadkach wystąpiła przewaga sumy ocen 1 i 2 nad ocenami 4 i 5). Okazało się zatem, że osoby starsze bardziej krytycznie niż osoby młodsze, oceniają otaczającą ich rzeczywistość, że dla znacznej ich liczby w okolicy ich miejsca zamieszkania występuje więcej potencjalnych zagrożeń.

Na podstawie oceny przez respondentów poszczególnych problemów społeczno-przestrzennych zbudowano skalę poczucia zagrożenia ${ }^{3}$. Zdecydowanie najbardziej liczną okazała się grupa charakteryzująca się średnim poczuciem zagrożenia

${ }^{3}$ Skala jest sumą wartości przyporządkowanych odpowiedziom w następujący sposób: randze 1 (nie stanowi to w ogóle problemu) przypisano wartość 1; randze 2 - wartość 2 itd. W ten sposób badani seniorzy uzyskali od 20 do 90 punktów (148 osób, gdyż nie uwzględniono braków odpowiedzi). Następnie badanych podzielono na cztery grupy w zależności od wartości skali, według przedziałów o równej rozpiętości. Grupy te charakteryzowały się wysokim, średnim bądź niskim poczuciem zagrożenia lub jego brakiem. W podobny sposób skale konstruowane były w opracowaniu J. Jerschiny z zespołem (2012). Wskaźnik oceny rzetelności skali $\alpha$-Cronbacha wyniósł 0,900. 
(tab. 1). W badanej grupie respondentów istotny statystycznie (choć na niskim ujemnym poziomie) okazał się związek poczucia zagrożenia z wykształceniem - im wyższe wykształcenie tym częściej respondenci charakteryzują się brakiem lub niskim poczuciem zagrożeń społeczno-przestrzennych. Poziom poczucia zagrożenia okazał się istotnie zróżnicowany przestrzennie $(V$ Kramera $=0,343$, $p<0,001)$. Charakterystyczne okazały się szczególnie postawy mieszkańców Radiostacji (odczuwają najczęściej zagrożenie niskie lub jego brak) i północnej części Centrum (coraz więcej osób wykazuje coraz wyższy stopień odczuwanego zagrożenia). Istotnie różnicującymi badaną populację osób w wieku $60+$ nie okazały się natomiast takie ich cechy, jak płeć, wiek i stan cywilny.

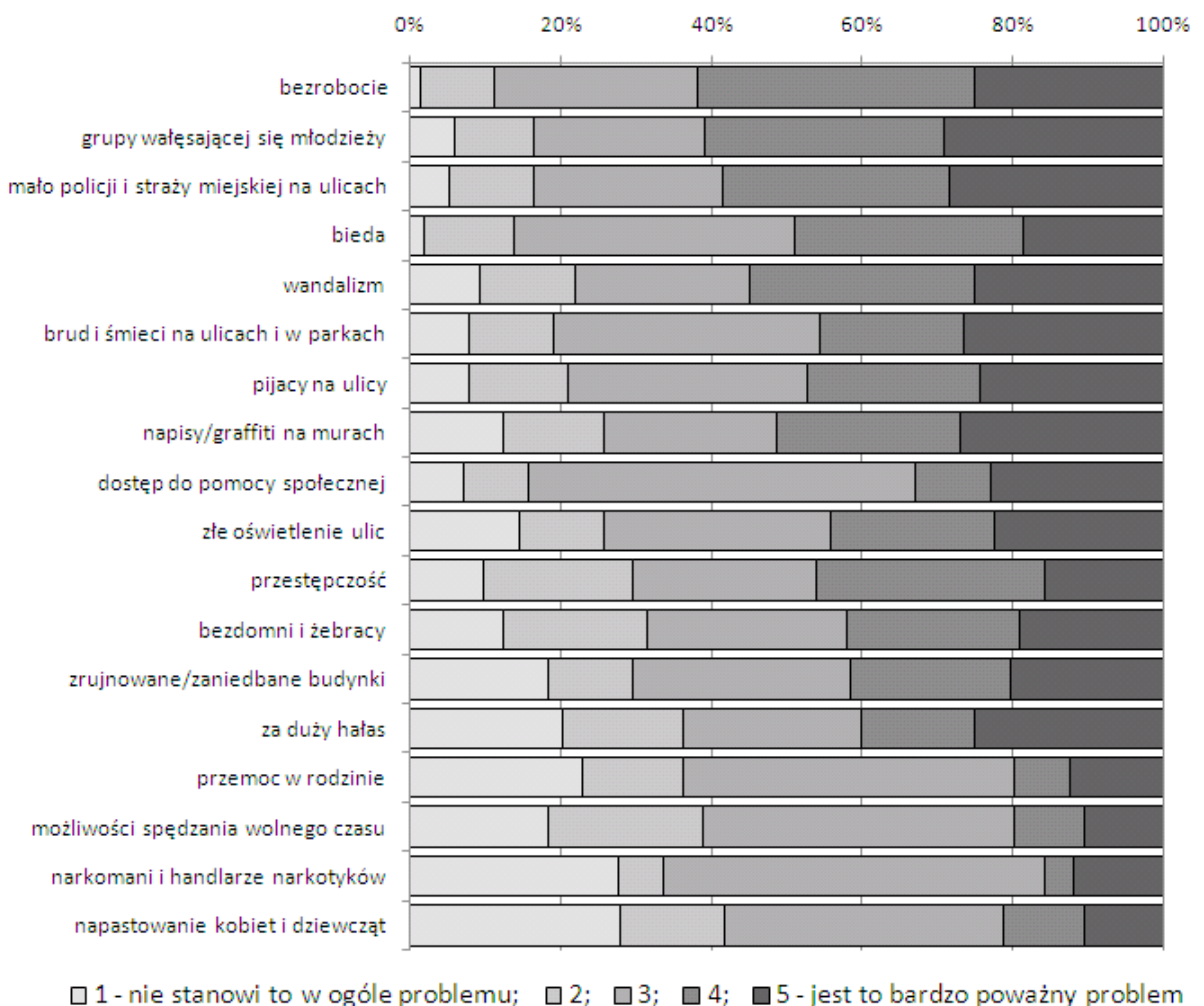

Rys. 1. Ocena problemów społeczno-przestrzennych

Źródło: opracowanie własne 
Poczucie zagrożenia według płci, wieku i wykształcenia respondentów

\begin{tabular}{|c|c|c|c|c|c|c|c|c|}
\hline \multirow{3}{*}{$\begin{array}{l}\text { Poziom } \\
\text { poczucia } \\
\text { zagroże- } \\
\text { nia }\end{array}$} & \multirow[b]{2}{*}{ Ogółem } & \multicolumn{2}{|c|}{ Płeć } & \multicolumn{2}{|c|}{ Wiek } & \multicolumn{3}{|c|}{ Wykształcenie } \\
\hline & & Kobieta & $\begin{array}{c}\text { Męż- } \\
\text { czyzna }\end{array}$ & $60-74$ & $75+$ & $\begin{array}{l}\text { Podsta- } \\
\text { wowe, } \\
\text { zawo- } \\
\text { dowe }\end{array}$ & Średnie & $\begin{array}{c}\text { Wyższe, } \\
\text { niepełne } \\
\text { wyższe }\end{array}$ \\
\hline & \multicolumn{8}{|c|}{$\mathrm{W} \%$} \\
\hline Brak & 8 & 7 & 11 & 8 & 7 & 2 & 13 & 25 \\
\hline Niskie & 29 & 26 & 35 & 28 & 36 & 33 & 23 & 25 \\
\hline Średnie & 48 & 50 & 44 & 50 & 39 & 44 & 58 & 44 \\
\hline Wysokie & 15 & 17 & 10 & 14 & 18 & 21 & 6 & 6 \\
\hline
\end{tabular}

Źródło: opracowanie własne.

\subsection{WIKTYMIZACJA SENIORÓW W LODZI}

\subsubsection{Doświadczenia wiktymizacyjne}

Spośród osób, które ukończyły 60 lat, mniejszość - 32,9\% respondentów ${ }^{4}$ - było ofiarą co najmniej jednego $\mathrm{z}$ dziesięciu zdarzeń uwzględnionych $\mathrm{w}$ badaniach (rys. 2). Badane osoby w wieku 60+ niestety doświadczyły sześciu czynów karalnych. Tylko czterem czynon nie uległ żaden z respondentów: pobicie i poranienie, seksualne napastowanie lub gwałt, kradzież z samochodu, kradzież samochodu). Największa liczba badanych przyznała, że w ciągu ostatniego roku została wulgarnie zaczepiona (16\%). Czyn ten, jakkolwiek nie wiąże się z ubytkiem materialnym bądź na zdrowiu fizycznym ofiary, ale może być dotkliwy dla psychiki poszkodowanego. Rzadziej seniorzy byli ofiarą kradzieży, nie połączonej z użyciem przemocy (12\%). Kolejne 7\% badanych osób mogło ponieść straty materialne związane z włamaniem do piwnicy lub komórki. Ogólnie można stwierdzić, że respondenci doświadczyli czynów skierowanych przeciwko ich mieniu i tylko $2 \%$ osób, które były ofiarami rozboju, mogły odnieść uszczerbek na zdrowiu.

$\mathrm{Na}$ podstawie deklaracji poszczególnych osób, które były poszkodowane w ciągu ostatniego roku określono wskaźnik, będący sumą zdarzeń, którym ulegli badani seniorzy (rys. 3). Przeważająca część respondentów $(67,1 \%)$ stwierdziła, że w ostatnim czasie nie przydarzył im się żaden z czynów, o który byli

${ }^{4} \mathrm{~W}$ grupie osób młodszych niż 60 lat, odsetek ten wyniósł 28,5\%. Z grupy tej $14 \%$ respondentów w ciągu ostatniego roku było ofiarą wulgarnej zaczepki, $8 \%$ - uszkodzenia samochodu, 5\% - włamania do piwnicy, 4\% - kradzieży z samochodu, 25\% - kradzieży, $2 \%$ - rozboju. Ponadto po kilka osób było poszkodowanych pozostałymi czynami. 
zapytywani ${ }^{5}$. Co czwarta badana osoba (24\%) wskazała tylko jedno zdarzenie, którym była poszkodowana, 7\% wskazało po dwa takie zdarzenia, a tylko $1 \%$ trzy czyny. Okazało się, że wśród badanych osób starszych więcej było ofiar wybranych czynów przestępczych, częściej także byli oni ofiarami wielokrotnymi.

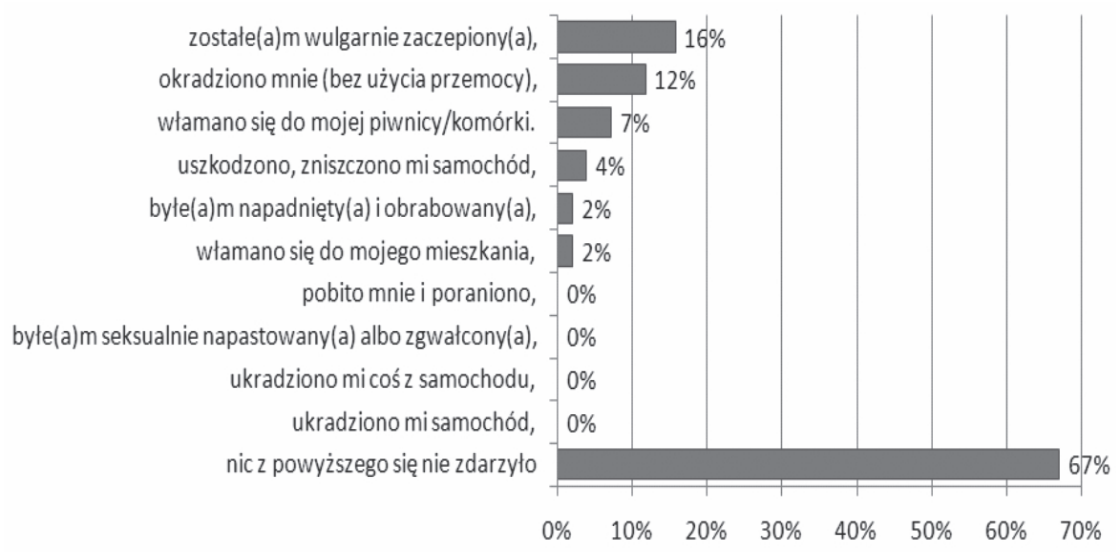

Rys. 2. Zdarzenia wiktymizacyjne, które miały miejsce w ciągu ostatniego roku

Źródło: opracowanie własne

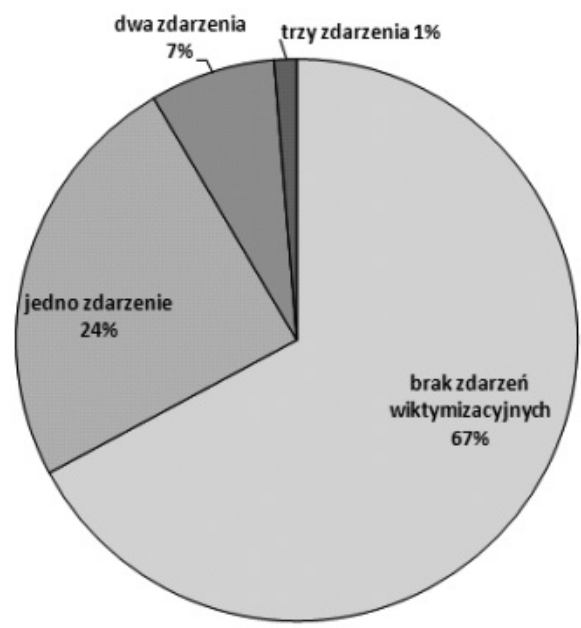

Rys. 3. Liczba zdarzeń wiktymizacyjnych w ciągu ostatniego roku Źródło: opracowanie własne

${ }^{5} \mathrm{~W}$ grupie osób, które nie ukończyły jeszcze 60 lat, odsetek ten wyniósł 71,5\%. Ofiarą jednego zdarzenia było $21,3 \%$ osób, dwóch zdarzeń - 5,9\%, trzech i więcej zdarzeń-1,3\%. 
Nie zaobserwowano istotnych statystycznie zależności między doświadczeniem wiktymizacyjnym a płcią, wiekiem, wykształceniem, stanem cywilnym czy zamieszkiwanym osiedlem. Natomiast istotna statystycznie jest zależność między faktem bycia ofiarą przestępstwa i poziomem poczucia zagrożenia respondentów (opisanym w poprzednim rozdziale tego artykułu; $V$ Kramera $=0,308, p<0,01$ ). W tabeli 2 można zauważyć, że seniorzy, którzy w ciągu ostatniego roku doświadczyli któregoś z przestępstw, znacznie rzadziej odczuwają w swoim środowisku zamieszkania brak zagrożeń lub ich niski poziom. Inaczej percypują ewentualne zagrożenia osoby, które nie były ofiarami.

Tabela 2

Poczucie zagrożenia a doświadczenie wiktymizacyjne respondentów

\begin{tabular}{|c|c|c|c|c|c|}
\hline \multirow{2}{*}{$\begin{array}{c}\text { Doświadczenie } \\
\text { wiktymizacyjne }\end{array}$} & $\begin{array}{c}\mid 4 \\
\text { brak } \\
\text { zagrożenia }\end{array}$ & niski & średni & \multirow{2}{*}{ wysoki } & \multirow{2}{*}{ Ogółem } \\
\cline { 2 - 5 } & \multicolumn{5}{|c|}{$(\mathrm{w} \%)$} \\
\hline Tak & 16,7 & 16,7 & 40,3 & 57,1 & 32,9 \\
\hline Nie & 83,3 & 83,3 & 59,7 & 42,9 & 67,1 \\
\hline
\end{tabular}

Źródło: opracowanie własne.

\subsubsection{Ryzyko wiktymizacji}

Ryzyko wiktymizacji (zostania ofiarą przestępstwa lub wykroczenia) mierzono za pomocą odpowiedzi na pytania o ocenę prawdopodobieństwa, że respondenci staną się ofiarami przestępstw na obszarze osiedla, które zamieszkują (w formularzu pytanie to odnosiło się do sześciu kategorii czynów). Za najbardziej prawdopodobne badane osoby starsze ${ }^{6}$ uznały, że ktoś może im coś ukraść bez użycia przemocy - że jest to prawdopodobne lub bardzo prawdopodobne, odpowiedziało łącznie 48\% osób (rys. 4a). Bardzo dużo osób, które ukończyły 60 lat obawiało się także wulgarnych zaczepek (razem 44\%) oraz bycia oszukanym przy kasie (40\%). Nieco niżej respondenci ocenili prawdopodobieństwo, że zostaną ofiarami rozboju ( $29 \%$ ) lub pobicia i poranienia $(26 \%)$. Za zupełnie nieprawdopodobne kobiety uznały szanse zostania ofiarą seksualnego napastowania lub gwałtu (7\%).

${ }^{6} \mathrm{~W}$ grupie osób młodszych, które nie ukończyły jeszcze 60 lat, struktura odpowiedzi na to pytanie była odmienna. W kolejności respondenci ci wykazali największe obawy związane z (łączny odsetek osób uznających dany czyn za bardzo prawdopodobny i prawdopodobny): wulgarnymi zaczepkami (39\%), okradzeniem (33\%), oszukaniem przy kasie (24\%), rozbojem $(17 \%)$, pobiciem i poranieniem (11\%) i seksualnym molestowaniem/ zgwałceniem (12\%). 
W przypadku wszystkich czynów karalnych (z wyjątkiem pobicia i poranienia) jedyną zmienną różnicującą opinie respondentów było miejsce zamieszkania na jednym z pięciu badanych osiedli ${ }^{7}$.

Jak się okazało, seniorzy określali prawdopodobieństwo zostania ofiarą wybranych czynów na zdecydowanie wyższym poziomie niż osoby młodsze. Jedynie ryzyko wulgarnego zaczepiania zostało określone na podobnym poziomie, a ryzyko napastowania seksualnego nawet mniej osób uznało za możliwe.

Częściej obawy związane z prawdopodobieństwem zostania ofiarą czynu zabronionego towarzyszyły seniorom - posiadaczom samochodów, rowerów, piwnic/komórek i mieszkań ${ }^{8}$ (rys. 2b). Ponad połowa (52\%) posiadaczy sądzi, że ich samochód może zostać uszkodzony, a ponadto obawiają się oni, że ich pojazd może zostać skradziony (44\%) lub przynajmniej, że coś z pojazdu może być przez kogoś ukradzione (41\%). Równie częste były obawy związane z okradzeniem piwnicy czy komórki (48\%) lub z ukradzeniem roweru (45\%). 34\% seniorów wyraziło natomiast wysokie obawy związane z włamaniem do ich mieszkań. W przypadku każdego z tych czynów osoby w wieku senioralnym wyżej niż młodsi respondenci oceniali ryzyko wiktymizacji. Szczególnie wyższe było ono w przypadku szans włamania do mieszkania, utraty pojazdu lub roweru.

W przypadku czynów wymienionych na rys. $4 \mathrm{~b}$ tylko niektóre $\mathrm{z}$ charakterystyk respondentów okazały się istotne w różnicowaniu ryzyka wiktymizacji. Najwyższe wartości wskaźnika $V$ Kramera obliczono dla prawdopodobieństwa, że coś zostanie ukradzione z samochodu seniora. Istotnymi cechami okazały się wykształcenie (większe obawy wykazały osoby lepiej wykształcone; $\mathrm{V}=0,449$ ) i płeć (większe ryzyko odczuwają kobiety; $\mathrm{V}=504$ ).

Na podstawie odpowiedzi na pytania określające ryzyko wiktymizacji, zbudowano syntetyczną skalę subiektywnego ryzyka wiktymizacji ${ }^{9}$. Skalę zbudowano w oparciu o siedem spośród dwunastu odpowiedzi - wyłączono odpowiedzi, dla których $\mathrm{N}$ było mniejsze niż 152 (patrz rys. 4ab). Wyznaczona skala pozwala na

${ }^{7}$ Wskaźniki $V$ Kramera okazały się istotne na poziomie co najmniej 0,05, ale przyjmowały wartości z przedziału 0,22-0,26.

${ }^{8} \mathrm{~W}$ grupie osób młodszych, które nie ukończyły jeszcze 60 lat, struktura odpowiedzi na to pytanie także była odmienna od odpowiedzi populacji osób starszych. Respondenci mający mniej niż 60 lat wykazali największe obawy związane z (łączny odsetek osób uznających dany czyn za bardzo prawdopodobny i prawdopodobny): uszkodzeniem samochodu (50\%), kradzieżą czegoś z samochodu (37\%), włamaniem do piwnicy/komórki (36\%), kradzieżą roweru (30\%), kradzieżą samochodu (25\%) i włamaniem do mieszkania (13\%).

${ }^{9}$ Skala jest sumą wartości przyporządkowanych odpowiedziom w następujący sposób: randze 1 (całkiem nieprawdopodobne) przypisano wartość 1; randze 2 - wartość 2 itd. W ten sposób respondenci uzyskali od 7 do 34 punktów. Następnie badanych podzielono na cztery grupy w zależności od wartości skali, według przedziałów o równej rozpiętości. Grupy te charakteryzowały się bardzo niskim, niskim, wysokim i bardzo wysokim ryzykiem wiktymizacji. Wskaźnik oceny rzetelności skali $\alpha$-Cronbacha wyniósł 0,875 . 


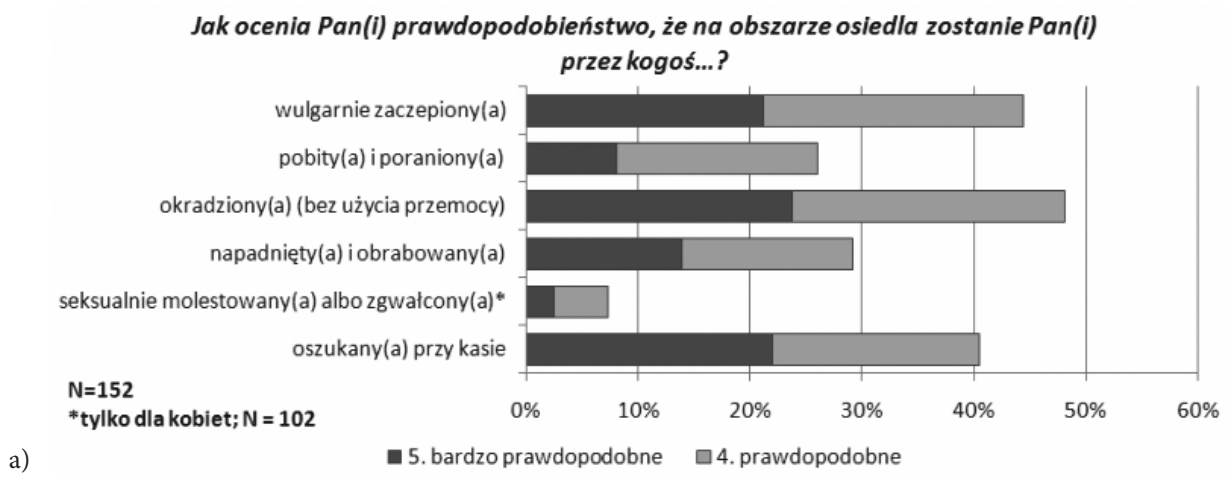

Jak ocenia Pan(i) prawdopodobieństwo, że na obszarze osiedla ktoś...?

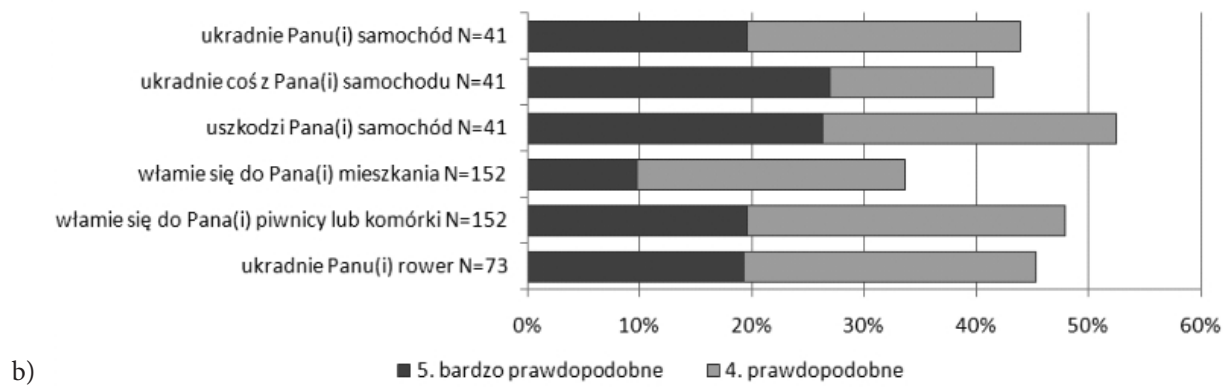

Rys. 4. Prawdopodobieństwo zostania ofiarą przestępstwa

Źródło: opracowanie własne

syntetyczną ocenę obaw respondentów związanych z byciem poszkodowanym przestępstwami. Im wyżej badane osoby, które ukończyły już 60 lat określały swoje ryzyko wiktymizacji poszczególnymi przestępstwami, tym większą wartość uzyskały w skali subiektywnego ryzyka wiktymizacji. Okazało się, że najwięcej badanych seniorów charakteryzowało się wysokim ryzykiem wiktymizacji (34\%) oraz ryzykiem niskim (31\%). Kolejne 19\% respondentów wyróżniało się bardzo wysokim ryzykiem wiktymizacji, a tylko dla $16 \%$ badanych cechowało bardzo niskie ryzyko. Poziom subiektywnego ryzyka wiktymizacji nie wykazał związku z płcią, wiekiem, wykształceniem czy stanem cywilnym badanych osób. Okazało się jednak, że jest ono statystycznie istotnie zróżnicowane przestrzennie $(V$ Kramera $=0,247, \mathrm{p}<0,05)-$ wyższe ryzyko bycia poszkodowanym przestępstwami cechowało mieszkańców osiedli Centrum-Północ i Doły, niższe natomiast ryzyko było charakterystyczne dla seniorów z osiedla Centrum-Południe.

Stwierdzono silną pozytywną zależność między subiektywnym ryzykiem wiktymizacji i poziomem poczucia zagrożenia ( $\rho$ Spearmana $=0,631 ; \mathrm{p}<0,01)$. Osoby percypujące więcej zagrożeń w swoim środowisku mieszkaniowym, 
częściej wskazują na wysokie ryzyko wiktymizacji. Jednak zastanawiająca jest ponadto wyraźna dysproporcja pomiędzy realnie niskim doświadczeniem wiktymizacyjnym badanych seniorów a wysokim deklarowanym poczuciem ryzyka wiktymizacyjnego. Więcej starszych osób obawia się, że zostaną ofiarami przestępstw niż faktycznie było takimi ofiarami (w grupie osób młodszych ta różnica jest zdecydowanie mniejsza). Wykazana została istotna zależność między doświadczeniem wiktymizacyjnym a subiektywnym ryzykiem wiktymizacyjnym ( $V$ Krame$\mathrm{ra}=0,375, \mathrm{p}=0,001)$. Osoby $\mathrm{w}$ wieku senioralnym, które nie były poszkodowane, w większości charakteryzują się bardzo niskim ryzykiem wiktymizacji.

\subsection{ZACHOWANIA OBRONNE PODEJMOWANE PRZEZ SENIORÓW}

Zachowania obronne mieszkańców, które podejmują oni w okolicy swojego miejsca zamieszkania, powinny być adekwatne do poziomu zagrożeń występujących w danym środowisku społeczno-przestrzennym, ewentualnie zmodyfikowanym przez osobiste doświadczenia jednostek. Jednym z celów badań było określenie skali stosowanych przez osoby starsze zachowań obronnych, które podejmują w celu ochrony przed potencjalnym zagrożeniem. W opracowaniach wielu autorów, tego rodzaju zachowania analizowane są w podziale na dwa typy strategii - pasywnych i aktywnych. Strategie/zachowania pasywne związane są z zachowaniami polegającymi na unikaniu sytuacji uznawanych za niebezpieczne, czyli na omijaniu pewnych miejsc, okoliczności i grup ludzi. W związku z tym badane osoby zostały zapytane o to, czy unikają: komunikacji publicznej wieczorem $i$ w nocy, miejsc nieoświetlonych po zmroku, podejrzanie wygladajacych grup lu$d z i$ oraz czy unikają samotnego wychodzenia z domu po zmroku. Strategie/zachowania aktywne polegają natomiast na podejmowaniu czynnych działań zmierzających do ochrony przed spodziewanym zagrożeniem. Respondenci odnosili się do pytań związanych z dodatkowym zabezpieczeniem domu/mieszkania przed włamaniem (np. zamek, alarm), zabieraniem ze sobą przedmiotów służących do obrony, wychodzeniem $\mathrm{z}$ domu po zmroku w towarzystwie innej osoby lub psa oraz związanych z udziałem osoby ankietowanej w kursie samoobrony. W przy padku obu rodzajów zachowań utworzone zostały skale pomiarowe, które pozwoliły na późniejsze określenie poziomu wykorzystania określonych strategii ${ }^{10}$. Jak się okazało, badane osoby, które ukończyły 60 lat, wykazywały 2,6 zachowań pasywnych, przy tylko 0,8 zachowania aktywnego ${ }^{11}$.

${ }^{10} \mathrm{~W}$ przypadku obu strategii, każdej twierdzącej odpowiedzi nadano wartość 1 , a przeczącej 0 . Następnie zsumowano te wartości - każdy respondent mógł otrzymać od 0 do 4 punktów. Współczynnik $\alpha$-Cronbacha przyjął wysokie wartości: dla skali strategii zachowań pasywnych 0,63 i 0,65 dla zachowań aktywnych.

${ }^{11}$ Osoby w wieku do 60 lat przeciętnie stosowały jeszcze mniej strategii zachowań obronnych: 1,9 zachowań pasywnych i 0,7 zachowania aktywnego. 
Podczas opracowywania wyników odpowiedzi, okazało się, że niektóre rodzaje pasywnej i aktywnej obrony były stosowane bardzo często (unikanie podejrzanie wyglądających osób lub grup ludzi, omijanie określonych miejsc, unikanie samotnego wychodzenia z domu po zmroku), inne były wykorzystywane bardzo rzadko (udziat $w$ kursie samoobrony, wychodzenie $z$ domu po zmroku $w$ towarzystwie innej osoby lub psa). Najczęściej spotykanym zachowaniem pasywnym okazało się unikanie przechodzenia w pobliżu podejrzanych osób lub grup, które wykazywało $88 \%$ seniorów ${ }^{12}$ (rys. 5). Znacznie częściej takich osób unikają kobiety $(94 \%)$ niż mężczyźni ( $V$ Kramera $=0,263, p=0,001)$. Ponadto okazało się, że zachowań takich istotnie nie różnicuje wiek, wykształcenie, stan cywilny, ani posiadane doświadczenie wiktymizacyjne. Opisywany rodzaj zachowań nie posiada także swojego wymiaru przestrzennego, chociaż zauważono, że nieco częściej tego typu strategię obronną stosowali mieszkańcy Radiostacji.

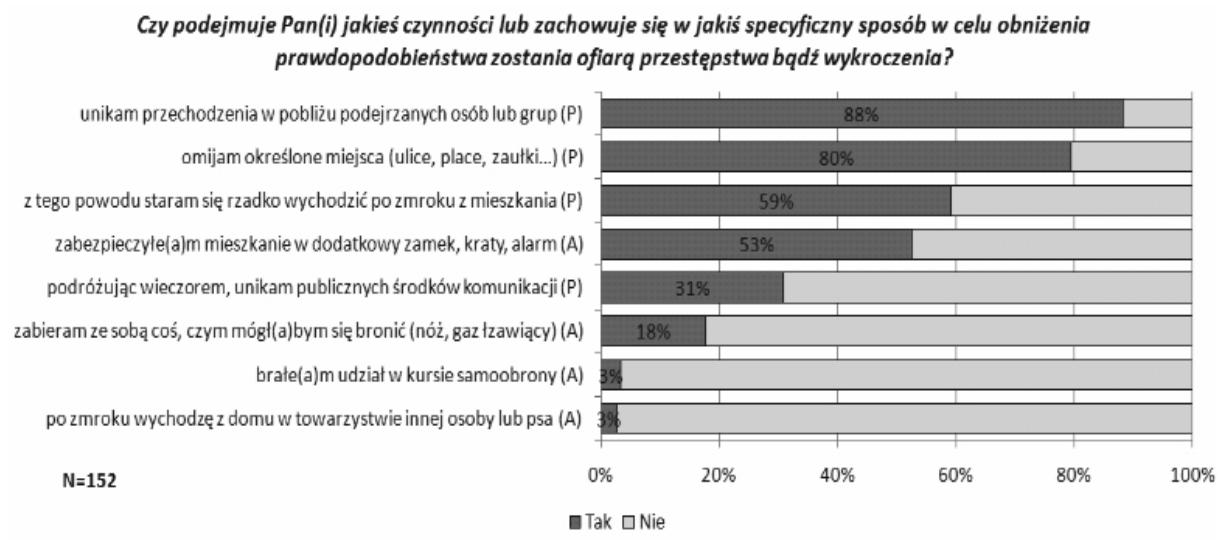

Rys. 5. Częstość podejmowanych działań obronnych przez osoby w wieku 60+ (uwaga: A - zachowania aktywne; $\mathrm{P}$ - zachowania pasywne)

Źródło: opracowanie własne

Drugim typowym pasywnym zachowaniem obronnym było omijanie określonych miejsc - tak postępuje $80 \%$ osób, które poddały się badaniu. W przypadku tego zachowania ponownie istotnymi zmiennymi okazała się tylko płeć ( $V$ Kramera $=0,236, p<0,01)$. Szczególnie często tego typu zachowania były wykazywane przez kobiety $-86 \%$.

${ }^{12}$ Odsetek osób z grupy młodszej, które stosowały zachowania obronne kształtował się następująco: unikanie przechodzenia w pobliżu podejrzanych osób lub grup - 77\%; omijanie określonych miejsc-71\%; rzadkie wychodzenie po zmroku z mieszkania-22\%; zabezpieczenie mieszkania $w$ dodatkowy zamek, kraty, alarm-40\%; unikanie publicznych środków komunikacji - 19\%; zabieranie ze soba czegoś do obrony (nóż, gaz tzawiacy) - 17\%; wzięcie udziatu w kursie samoobrony - 13\%; wychodzenie z domu po zmroku $w$ towarzystwie innej osoby lub psa-3\%. 
Seniorzy także często deklarowali unikanie samotnego wychodzenia z domu po zmroku. W tym przypadku analiza nie jest jednoznaczna, gdyż niektóre osoby w trakcie przeprowadzania wywiadów mówiły, że po prostu nie mają takiej potrzeby. W takich przypadkach niewychodzenie $\mathrm{z}$ domu nie może być interpretowane w kategoriach reakcji, bądź jej braku, na sytuację zagrożenia. Otrzymane opinie respondentów potwierdzają raczej opisywane w literaturze zjawisko, jakim jest ogólnie niska skłonność Polaków do wychodzenia z domu i wykazywania różnych zachowań wieczorem poza domem. Dotyczy to zarówno niskiego poziomu uczestnictwa w wydarzeniach kulturalnych i rozrywkowych, ale także zwykłych spotkań towarzyskich w restauracjach czy pubach. Z uzyskanych odpowiedzi wynika, że zachowanie to istotnie statystycznie uzależnione jest od stanu cywilnego respondentów i posiadanego doświadczenia wiktymizacyjnego. Częściej zachowanie to jest podejmowane przez osoby pozostające w stanie wolnym $(67 \%$; $V$ Kramera $=0,183, \mathrm{p}<0,01)$, niż przez będących $\mathrm{w}$ stanie małżeńskim. Osoby, które były ofiarą jakiegoś czynu karalnego, częściej deklarują pozostawanie wieczorem w domu $(70 \%$; $V$ Kramera $=0,163, \mathrm{p}<0,05)$.

Właściwie jedynym aktywnym zachowaniem obronnym często wyrażanym przez respondentów było zabezpieczenie mieszkania $w$ dodatkowe urzadzenia (zamek, kraty, alarm). Deklarowała to ponad połowa osób w wieku 60+. W przypadku tego technicznego środka zabezpieczeń, tylko osoby posiadające doświadczenie wiktymizacyjne częściej deklarowały jego stosowanie $(66 \%$; $V$ Kramera $=0,182, p<0,05)-$ wpływ pozostałych charakterystyk respondentów okazał się nieistotny. Zdaniem autora, dodatkowe zabezpieczanie mieszkań przez tylko około połowę respondentów, to bardzo niski wskaźnik, zważywszy na niski standard powszechnie stosowanych podstawowych zabezpieczeń w blokach spółdzielczych i domach komunalnych. Okazuje się jednak, że tak dużo starszych osób wierzy w skuteczność standardowych zabezpieczeń i nie jest zainteresowana poprawą swojego bezpieczeństwa tymi środkami.

Podsumowując, respondenci w celu zwiększenia swojego poczucia bezpieczeństwa i zapobieżenia ewentualnym zagrożeniom zdecydowanie częściej podejmowali pasywne strategie zachowań obronnych (rys. 6). Warte podkreślenia jest, że aż 38\% badanych osób nie podjęło żadnego z przedstawionych zachowań aktywnych, podczas gdy w przypadku zachowań pasywnych było to tylko $8 \%$. Ponadto żaden senior nie potwierdził stosowania wszystkich czterech strategii zachowań aktywnych, wobec $24 \%$ respondentów stosujących wszystkie wymienione w kwestionariuszu zachowania pasywne.

Z przeprowadzonych dodatkowo analiz porównawczych okazało się, że osoby, które jeszcze nie ukończyły 60 roku życia, rzadziej niż osoby w wieku 60 wzwyż stosują opisywane zachowania obronne. Szczególnie dużą dysproporcję $(+38 \%$ stosujących je osób - na korzyść seniorów) zauważono w przypadku stosowania nie wychodzenia po zmroku z mieszkania lub domu. Za to jedynym częściej podejmowanym działaniem przez osoby w młodszym wieku było wzięcie udziału 

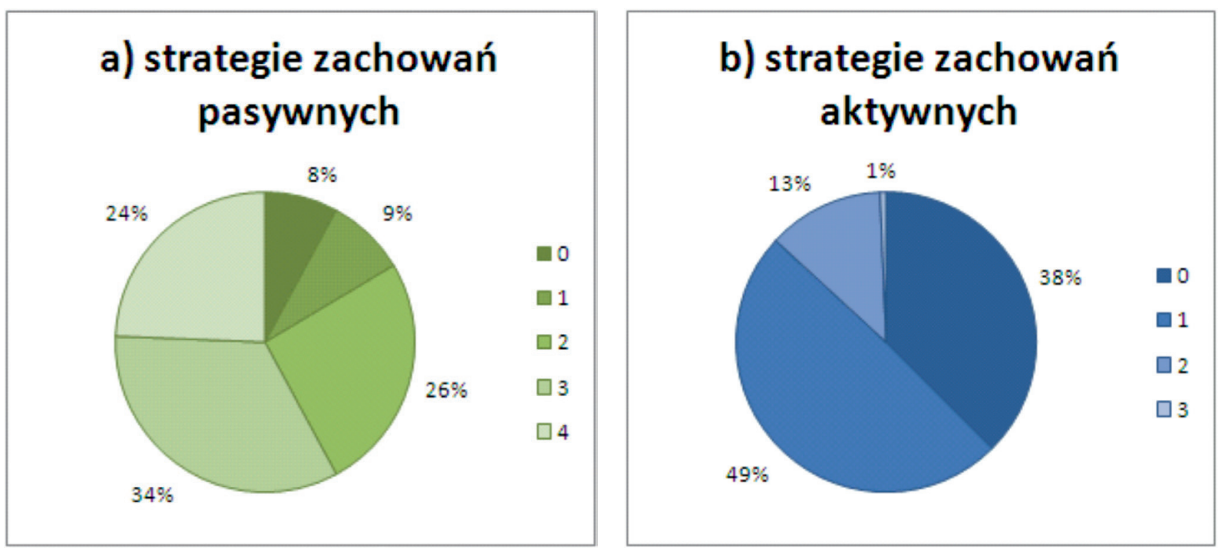

Rys. 6. Liczba podejmowanych przez seniorów strategii zachowań obronnych Źródło: opracowanie własne

w kursie samoobrony. Wydaje się zatem, że podwyższony w grupie osób w wieku senioralnym poziom percypowanych zagrożeń środowiskowych i poziom subiektywnego ryzyka wiktymizacji może być przyczyną częstszego podejmowania przez tę grupę zachowań obronnych.

Jednym z podstawowych celów badań było zatem sprawdzenie na ile stosowane strategie zachowań obronnych zależą od subiektywnego poczucia zagrożenia i subiektywnego ryzyka wiktymizacji (tab. 3).

Tabela 3

Podejmowane strategie obronne a poziom poczucia zagrożenia i subiektywne ryzyko wiktymizacji

\begin{tabular}{|c|c|c|c|}
\hline \multirow{2}{*}{\multicolumn{2}{|c|}{ Wyszczególnienie }} & \multicolumn{2}{|c|}{$\begin{array}{l}\text { Liczba podejmowanych strategii } \\
\text { zachowań obronnych }\end{array}$} \\
\hline & & $\begin{array}{c}\text { Zachowania } \\
\text { pasywne }\end{array}$ & $\begin{array}{c}\text { Zachowania } \\
\text { aktywne }\end{array}$ \\
\hline \multicolumn{2}{|c|}{ Ogółem } & 2,57 & 0,76 \\
\hline \multirow{4}{*}{$\begin{array}{l}\text { Poziom poczucia } \\
\text { zagrożenia }\end{array}$} & Brak & 2,08 & 0,50 \\
\hline & Niskie & 2,44 & 0,51 \\
\hline & Średnie & 2,58 & 0,89 \\
\hline & Wysokie & 3,05 & 1,00 \\
\hline \multirow{4}{*}{$\begin{array}{l}\text { Subiektywne } \\
\text { ryzyko } \\
\text { wiktymizacji }\end{array}$} & Bardzo niskie & 2,30 & 0,45 \\
\hline & Niskie & 2,58 & 0,63 \\
\hline & Wysokie & 2,61 & 0,92 \\
\hline & Bardzo wysokie & 3,17 & 1,09 \\
\hline
\end{tabular}

Źródło: opracowanie własne. 
Na zachowania obronne istotny wpływ ma poziom poczucia zagrożenia. Osoby o wysokim poziomie poczucia zagrożenia wykazują więcej zachowań obronnych - zarówno tych pasywnych $(\rho$ Spearmana $=0,209, \mathrm{p}<0,05)$, jak i aktywnych ( $\rho$ Spearmana $=0,287, \mathrm{p}<0,001)$. Także subiektywne ryzyko wiktymizacji znajduje swoje odzwierciedlenie $w$ liczbie podejmowanych zachowań obronnych: pasywnych $(\rho$ Spearmana $=0,221, \mathbf{p}<0,05)$ i aktywnych $(\rho$ Spearmana $=0,333$, $\mathrm{p}<0,001)$. W kwestii tych relacji uzyskany obraz jest jasny: im niższy jest poziom poczucia zagrożenia, a także im niższe jest subiektywne ryzyko wiktymizacji, tym mniej zachowań obronnych badane osoby wykazują. Oby tylko, paradoksalnie, wysokie poczucie bezpieczeństwa i rzadko stosowane zachowania obronne, nie uśpiły nadto czujności osób w wieku senioralnym, bo wówczas łatwo mogłyby stać się ofiarą.

Zatem: percepcja zagrożeń społeczno-przestrzennych i ocena ryzyka wiktymizacji - w przypadku osób w wieku powyżej 60 lat przekłada się na realnie podejmowane przez nich zachowania obronne.

\subsection{PODSUMOWANIE}

W porównaniu z opracowaniami dotyczącymi poczucia bezpieczeństwa mieszkańców różnych miast, łodzianie generalnie charakteryzują się wyższym poczuciem zagrożenia, a przy tym stosują mniej różnych strategii zachowań obronnych. $\mathrm{W}$ trakcie badań przeprowadzonych na potrzeby tego artykułu okazało się, że osoby w wieku $60+$ wykazują się jeszcze wyższym poczuciem zagrożenia niż młodsze grupy łodzian, ale jednocześnie stosują przy tym więcej strategii obronnych (głównie o charakterze pasywnym).

W toku przeprowadzonych analiz udało się potwierdzić słuszność postawionej hipotezy o zróżnicowaniu postaw związanych z zachowaniami obronnymi, będących reakcją na dysproporcje przestrzenne różnorodnych zagrożeń i patologii społeczno-przestrzennych oraz oceny ryzyka wiktymizacji mieszkańców miasta będących w wieku senioralnym. W prezentowanych tutaj badaniach, zaobserwowano istotny i pozytywny związek między poziomem poczucia zagrożenia, odczuwanym ryzykiem wiktymizacyjnym a liczbą podejmowanych strategii obronnych. Stwierdzić można zatem, że w przypadku osób starszych, poczucie zagrożenia i ryzyko wiktymizacji są konsekwencją występujących problemów w danym środowisku społeczno-przestrzennym, co z kolei wpływa na ich zachowania. Okazało się, że łodzianie należący do najstarszej grupy wiekowej, odróżniają się wyraźnie w swoich opiniach od swoich młodszych sąsiadów. Po pierwsze, krytyczniej oceniają oni rożnego rodzaju problemy występujące w przestrzeni ich miasta, a także wyżej oceniają ryzyko, że mogą zostać poszkodowani, stać się ofiarami różnych zdarzeń. W rezultacie takiej percepcji łódzkiej przestrzeni, starają się oni częściej podejmować kilka wybranych strategii obronnych. 
We wcześniejszych badaniach (np. Mordwa 2013, 2014) bardzo często okazywało się, że poszczególne komponenty poczucia bezpieczeństwa oraz konsekwencje, które powodują, mają swój wyraźny wymiar przestrzenny. W tych badaniach ustalono, że w przypadku starszej grupy wiekowej uwarunkowania przestrzenne rzadko różnicują percepcję zagrożeń, subiektywne ryzyko wiktymizacji i podejmowane działania obronne.

\section{LITERATURA}

Bauman Z., 2004, Życie na przemiat, Wydawnictwo Literackie, Kraków.

Czapiński J., Panek T. (red.), 2009, Diagnoza społeczna 2009, Rada Monitoringu Społecznego, Warszawa, załącznik 2.

Czapska J., 2008, Poczucie bezpieczeństwa mieszkańców Krakowa, [w:] Krajewski K. (red.), Poczucie bezpieczeństwa mieszkańców wielkich miast, Wydawnictwo UJ, Kraków, s. 143-200.

Dzieciuchowicz J., 2011, Środowisko mieszkaniowe wielkiego miasta. Przyklad Łodzi, Wydawnictwo UŁ, Łódź.

Erikson E.H., 2002, Dopetniony cykl życia, Rebis, Warszawa.

Grotowska-Leder J., 2001, Przestrzeń miejska a zjawiska upośledzenia społecznego (na przykładzie Łodzi), [w:] Rogacki H. (red.), Koncepcje teoretyczne i metody badań geografii społeczno-ekonomicznej i gospodarki przestrzennej, Bogucki Wydawnictwo Naukowe, Poznań, s. 215-227.

Instytucje wobec potrzeb osób starszych. Raport, 2010, Instytutu Rozwoju Służb Społecznych, Warszawa.

Jabkowski P., 2008, Poczucie bezpieczeństwa i poziom przestępczości w Poznaniu. Analiza socjologiczna w perspektywie wskaźników jakości życia, [w:] Jakubowski J., Wątroba J. (red.), Zastosowania metod statystycznych $w$ badaniach naukowych III, Kraków, s. 203-212.

Jabkowski P., Kilarska A., 2013, Poczucie bezpieczeństwa i poziom przestępczości w Poznaniu, Wydawnictwo Naukowe UAM, Poznań.

Jerschina J., Lesińska E., Pytliński Ł., Siwek H., 2012, Badania poczucia bezpieczeństwa mieszkańców Prądnika Czerwonego w Krakowie ze szczególnym uwzględnieniem wpływu zmian architektonicznych i technicznych na poziom lęku przed przestępczościa, [w:] Czapska J. (red.), Zapobieganie przestępczości przez ksztaltowanie przestrzeni, Wydawnictwo UJ, Kraków.

Mordwa S., 2010, Poczucie bezpieczeństwa mieszkańców wybranych osiedli w Łodzi, [w:] Madurowicz M. (red.), Wartościowanie wspótczesnej przestrzeni miejskiej, WGSR UW, Warszawa.

Mordwa S., 2011, Poczucie bezpieczeństwa w Łodzi. Przykład badań mieszkańców osiedli mieszkaniowych, ,Space-Society-Economy”, 10, s. 181-196.

Mordwa S., 2012, Poczucie bezpieczeństwa w centrach handlowych. Przyklad badań opinii klientów Galerii Łódzkiej i Manufaktury w Łodzi, „Acta Universitatis Lodziensis. Folia Geographica Socio-Oeconomica", 12, s. 163-187. 
Mordwa S., 2013, Przestępczość i poczucie bezpieczeństwa w przestrzeni miasta. Przykład Łodzi, Wydawnictwo UŁ, Łódź.

Mordwa S., 2014, Dysproporcje przestrzenne wybranych zjawisk patologii spolecznych w Łodzi, [w:] Suliborski A, Wójcik M. (red.), Dysproporcje społeczne i gospodarcze w przestrzeni Łodzi. Czynniki, mechanizmy, skutki, Wydawnictwo UŁ, Łódź, s. 277-303.

Mordwa S., 2015, Przestrzenne i demograficzne uwarunkowania zróżnicowania poczucia bezpieczeństwa mieszkańców miasta, [w:] Wołk A., Potasińska A. (red.), Nierówności społeczne we współczesnym świecie, Wydawnictwo UKSW, Warszawa, s. 193-208.

Rosset E., 1959, Proces starzenia się ludności, PWG, Warszawa.

Suliborski A., Wójcik M. (red.), 2014, Dysproporcje społeczne i gospodarcze w przestrzeni Łodzi. Czynniki, mechanizmy, skutki, Wydawnictwo UŁ, Łódź.

Synak B., 2000, Pozycja społeczna ludzi starych $w$ warunkach zmian ustrojowych $i$ cywilizacyjno-ustrojowych, [w:] Synak B. (red.), Ludzie starzy w warunkach transformacji ustrojowej, Wydawnictwo Uniwersytetu Gdańskiego, Gdańsk.

Warzywoda-Kruszyńska W. (red.), 2001, (Żyć) Na marginesie wielkiego miasta, Absolwent, Łódź.

Zięba R., 1997, Kategoria bezpieczeństwa w nauce o stosunkach międzynarodowych, [w:] Bobrow D.B., Haliżak E., Zięba R. (red.), Bezpieczeństwo narodowe i międzynarodowe u schytku XX wieku, Wydawnictwo Scholar, Warszawa.

\begin{abstract}
In this paper the diversity of defensive behavior of people aged over 60 years was confirmed. The author analyzes the research results with regard to two main aspects of defensive behavior: perception of the socio-spatial threats and subjective risk of victimization. In the study there was observed a significant and positive relationship between the level of insecurity, perceived risk of victimization and the number of taken defensive strategies by residents in the age $60+$. There were also concluded that a sense of security and risk of victimization are a consequence of the problems identified in the socio-spatial environment of the elderly, which in turn affects their behavior.
\end{abstract}

\title{
Key words
}

Defensive behaviour, sense of security, socio-spatial threats, risk of victimization, Łódź. 